\title{
Implementasi Dan Analisis Server BigBlueButton Dalam Pemanfaatan Meeting Online Pada Masa Pandemic
}

\author{
Alan Budi Kusuma ${ }^{1}$, Amir Yusuf ${ }^{2}$, Alfian Hidayat ${ }^{3}$ \\ 123 Universitas Islam Negeri Walisongo \\ 1 alan@walisongo.ac.id, ${ }^{2}$ amiryusuf924@gmail.com, ${ }^{3}$ alfianguide@outlook.com
}

\begin{abstract}
The need for video conversion is something that cannot be ignored. In the midst of the Covid19 pandemic outbreak, video conferencing was the main alternative for communication to continue so that business processes at agencies also did not stop completely. Likewise with UIN Walisongo Semarang, through the BigBlueButton application that has been implemented can be an alternative to online meetings where the existing features are sufficient to meet all meeting needs. In addition, a special server has also been prepared and then conducted monitoring and analysis which results that the BigBlueButton server at UIN Walisongo can accommodate more than 200 participants who can conduct online meetings simultaneously.
\end{abstract}

Keyword $\quad$ : Online Learning, Online Meeting, Video Conference, Virtual Meeting

\section{Abstrak}

Kebutuhan akan video converence saat ini merupakan sesuatu yang tidak bisa untuk diabaikan. Di tengah wabah pandemic Covid-19, video conference merupakan alternatif utama agar komunikasi tetap berjalan sehingga proses bisnis di instansi pun juga tidak terhenti sepenuhnya. Begitu halnya dengan UIN Walisongo Semarang, melalui aplikasi BigBlueButton yang telah diimplementasikan dapat menjadi alternatif dari meeting online di mana dengan fasilitas yang ada sudah cukup memenuhi kebutuhan meeting. Selain itu, juga telah disiapkan sebuah server khusus lalu dilakukan monitoring serta analisis yang memberikan hasil bahwa server BigBlueButton di UIN Walisongo ini mampu menampung lebih dari 200 peserta yang dapat melakukan meeting online secara bersamaan.

Kata Kunci: Konferensi Video, Rapat Online, Pertemuan Online, Pembelajaran Online

ISSN 2715-0143 (online) ISSN 2714-9048 (print)

http://journal.walisongo.ac.id/index.php/iit/index 


\section{PENDAHULUAN}

Perkembangan teknologi semakin hari semakin maju dan berkembang pesat. Hampir semua sektor memanfaatkan teknologi informasi sebagai penunjang untuk membantu proses bisnisnya. Seperti halnya dalam sektor pendidikan, di mana banyak sekali teknologi informasi ini dipergunakan. Untuk mahasiswa dan dosen, melalui sistem informasi akademik, media pembelajaran online, dan aplikasi aplikasi yang berkaitan dengan teknologi informasi ini banyak digunakan. Sedangkan untuk tenaga kependidikan teknologi informasi digunakan untuk menunjang kegiatan sehari-hari seperti sistem absensi online, sistem keuangan, sistem penjaminan mutu akademik, dan sistem yang lainya.

Dalam masa saat ini, di tengah pandemic wabah covid-19 di akhir tahun 2019 ini, organisasi dunia who menyatakan bahwa kasus virus covid19 ini merupakan pandemic global, dimana untuk memutus mata rantai ini WHO memberikan solusi untuk tetap berada di rumah (StayatHome) sebagai upaya dalam memutus mata rantai virus ini. Dan pemerintah Indonesia, melalui peraturan pemerintah terutama Kementerian Agama dengan Surat Edaran nomor 5 Tahun 2020 Tentang Penyesuaian Sistem Kinerja Pegawai Dalam Upaya Pencegahan Penyebaran Corona Virus Disease 2019 (covid19) Pada Kementerian, mewajibkan semua sektor pendidikan dibawah kementerian agama untuk saat ini meliburkan sementara. Sebagai gantinya untuk para mahasiswa diberikan tugas untuk tetap belajar dirumah, dan untuk tenaga kependidikan untuk bekerja dirumah (Work From Home).

Mulai dari sini, masalah timbul karena hampir semua aktifitas yang biasa dilakukan secara offline, karena wabah ini semua terpaksa harus dilakukan secara online. Mulai dari kelas offline yang biasa dilakukan di dalam kelas, sekarang harus dilakukan dari rumah masing masing. Rapat yang biasa dilakukan didalam ruangan tertutup sekarang harus dilakukan melalui rumah sendiri. Sehingga komunikasi yang biasa dilakukan langsung sekarang harus menggunakan media online.

Sebenarnya sudah ada beberapa aplikasi - aplikasi yang dapat digunakan untuk media online untuk media rapat / pertemuan online, seperti google melalui aplikasi Google Meetnya, Zoom, Jitsi dan Whatsapp pun juga bisa kita gunakan melalu fitur VideoCall nya. Tetapi setiap dari aplikasi ini mempunyai fitur masing - masing dengan kekurangan dan kelebihanya.

Melihat dari hasil analisis yang dilakukan oleh PT. Tri Indonesia dari ke empat aplikasi video conference berdasarkan bandwidth yang dilakukan selama 30 menit dengan lima partisipan maka didapati hasil bahwa diantara 4 aplikai video conferemce yakni zoom, skype, hangouts, dan webex. zoom merupakan aplikasi yang hanya membutuhkan bandwidth terkecil yakni sekitar 700kbps. 


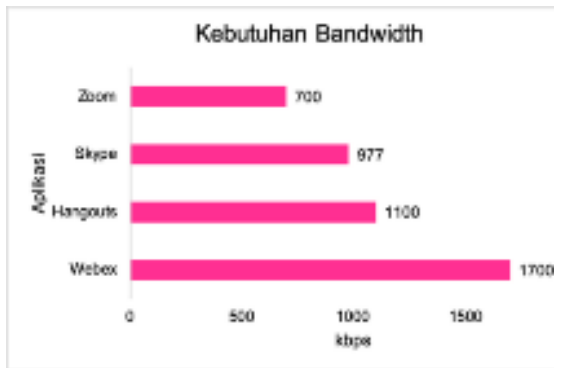

Gambar 1

Hasil kebutuhan Bandwidth yang dilakukan oleh Tri Indonesia

Hanya saja, ada hal lain yang perlu diperhatikan. Menurut Surat Edaran Kementerian Pertahanan RI no SE/57/IV/2020 Tentang Aplikasi Teleconverence Zoom Tidak di perkenankan / digunakan di lingkungan Kementerian Pertahanan Terkait Pengamanan Informasi Data.

Sedangkan menurut Badan

Siber Dan Sandi Negara (BSSN) tentang Artikel yang Berjudul "Telaah Staf Terkait Pemanfaatan Aplikasi Zoom Sebagai Media Online Meeting Yang Banyak Digunakan Saat Ini", dalam sarannya bagi pengguna zoom terutama instansi pemerintah yang menggunakan zoom bisa memperhatikan beberapa langkah langkah seperti yang disebutkan dalam artikelnya. Jadi sifatnya tidak melarang secara penuh, seperti dalam internal kementerian pertahanan RI.

Untuk itu, didalam tulisan ini, penulis mencoba untuk mencari media / alternatif lain yang jarang digunakan dalam menggunakan meeting online selain diatas. Yakni, menggunakan aplikasi BigBlueButton. Dimana aplikasi ini adalah aplikasi untuk video conference berbasis sumber terbuka (opensource) yang digunakan secara bebas dan gratis yang dapat menjadi alternatif dari media video conference yang ada.

Sebelum penilitian ini dibuat, sudah ada penelitian-penelitian sebelumnya yang menggunakan BigBlueButton sebagai media video conference, hanya saja kebanyakan penelitian tersebut masih menggunakan versi lama di tahun 2016 dimana masih menggunakan teknologi flash dalam implementasinya sehingga berdampak pada pengguna harus menginstall plugin flashplayer pada browsernya sehingga dirasa tidak flexible untuk mobile. Hal ini bisa dilihat melalui antarmuka versi lama pada penelitian Pengembangan Web Conference pada Modul E-Learning Dokeos yang ditulis oleh Jefri Valentino Karibi, dkk.

Sedangkan pada tulisan ini dibuat, BigBlueButton sudah meluncurkan versi 2.2.2 dimana sudah mendukung teknologi HTML5 yang sudah bisa menjalankan multimedia langsung tanpa menginstall plugins tambahan sehingga bisa dijalankan langsung di browser seperti chrome, firefox atau browser lain yang sudah mendukung html5 baik di desktop maupun di mobile.

Selain teknologi diatas, dan yang menjadi alasan yang terpenting adalah penulis ingin mengimplementasikan BigBlueButton sebagai media meeting online ini karena aplikasi ini dapat diinstall di server milik perguruan tinggi atau instansi, sehingga keamanan data dapat terjaga dan resource internet 
serta hardware milik UIN Walisongo dapat digunakan secara maksimal.

\section{METODE}

Metode penelitian yang digunakan dalam penulisan ini. Beberapa diantaranya :

a. Pengumpulan data

Pengumpulan data digunakan untuk mencari informasi sebanyak mungkin dalam membangun sistem menggunakan BigBlueButton ini.

Pengumpulan data diambil dari beberapa sumber yang paling utama adala website dari BigBlueButton sendiri yang beralamat di https://BigBlueButton.org/

b. Analisa dan perancangan sistem

Dalam tahap ini dilakukan analisa kebutuhan sistem, mulai dari spesifikasi minimal hardware, software, dan minimum bandwidth yang dibutuhkan dalam proses instalasi. Serta domain yang nanti akan digunakan untuk mengkases server Virtual conference ini.

c. Implementasi

Dalam tahap ini mulai dilakukan instalasi BigBlueButton, ada beberapa tahapan :

1. Instalasi hardware / Server

2. Instalasi Sistem Operasi

3. Pendaftaran subdomain

4. Instalasi BigBlueButton

\section{d. Pengujian}

Pada tahap ini mulai dilakukan pengujian dari aplikasi
BigBlueButton, mulai dari membuat akun, membuat room, menjalankan room, dan mengexplore fitur - fitur yang ada di BigBlueButton itu sendiri.

\section{KERANGKA TEORI}

\section{a. Sistem Informasi}

Menurut John F.Nash (1995) Sistem informasi merupakan sebuah kombinasi dari manusia, teknologi, media, prosedur serta pengendalian yang ditujukan untuk mengatur jaringan komunikasi, proses transaksi tertentu, membantu manajemen dan menyediakan dasar untuk pengambilan keputusan yang tepat.

\section{b. Hardware}

Menurut James O'Brain (2008) Hardware adalah semua peralatan fisik yang digunakan dalam pemrosesan informasi, termasuk diantaranya $C P U, R A M$, monitor, mouse, keyboard, printer, scanner, dan lain-lain.

Perangkat keras merupakan media komunikasi yang menghubungkan beberapa jaringan dan memproses paket data sehingga transmisi data lebih efektif.

\section{c. Software}

Pengertian software menurut gagasan yang disampaikan oleh Roger S. Pressman (2002), Pressman menyebutkan bahwa perangkat lunak atau software merupakan suatu perintah program yang teradapat di dalam sebuah komputer yang apabila dieksekusi oleh 
penggunanya akan memberikan sejumlah fungsi sekaligus menampilkan informasi yang diinginkan oleh penggunanya.

Pernyataan ini memberikan gambaran jika software atau perangkat lunak ini memiliki fungsi untuk memberikan perintah kepada komputer agar komputer bisa menjalankan fungsi dengan maximal, sesuai dengan kemauan pengguna yang akan memberikan perintah.

d. BigBlueButton

BigBlueButton merupakan aplikasi berbasi web yang bersifat opensource (sumber terbuka) yang berfungsi sebagai sistem konferensi yang dapat digunakan sebagai media pembelajaran atau meeting secara online. Proyek BigBlueButton mempunyai tujuan untuk memberikan pengalaman belajar daring berkualitas untuk siswa jarak jauh.

e. Video Conference

Konferensi video adalah seperangkat teknologi telekomunikasi interaktif yang memungkinkankan dua pihak atau lebih di lokasi berbeda dapat berinteraksi melalui pengiriman dua arah audio dan video secara bersamaan.

\section{PEMBAHASAN}

\section{a. Pengumpulan Data}

Pada awal pembahasan ini, dimulai dengan pengumpulan data. Dimana rujukan utama dari penelitian ini bersumber dari dokumentasi BigBlueButton yang disediakan oleh developernya yang bisa dilihat dari website https://docs.BigBlueButton.org/.

Selain itu pengumpulan data juga diperoleh dari beberapa penelitian yang pernah ada seperti jurnal milik Jefri Valentino Karibi, dkk, dengan judul "Pengembangan Web Conference pada Modul ELearning Dokeos" yang terbit pada tahun 2013, dan jurnal milik Muhammad Ismail, dkk dengan judul "Perancangan dan implementasi E-learning menggunakan Moodle dan Vicon untuk pelajaran Pemrograman Web di SMK" yang terbit pada tahun 2016.

b. Analisa dan Perancangan Sistem

Setelah dilakukan pengumpulan data maka langkah selajutnya adalah analisa dan perancangan sistem. Analisa ini perlu dilakukan sebelum dilakukan proses instalasi / implementasi.

Analisa yang dilakukan saat ini adalah melihat kebutuhan minimal untuk membangun server BigBlueButton dan menyesuiakan dengan resource yang dimiliki. Dalam dokumentasi yang ada di website, maka pengembang memberikan rekomendasi sepesifikasi minimal hardware seperti berikut : 
Tabel 1

Spesifikasi minimal hardware

\begin{tabular}{|l|l|}
\hline Hardware & Minimal \\
\hline CPU & 4 Core atau lebih \\
\hline RAM & 8 GB atau lebih \\
\hline Hardisk & $\begin{array}{l}500 \mathrm{~Gb} \text { atau lebih } \\
\text { untuk hasil } \\
\text { rekaman }\end{array}$ \\
\hline
\end{tabular}

Sedangkan untuk kebutuhan Software minimal yang direkomendasikan oleh pengembang seperti berikut:

Tabel 2

Spesifikasi minimal Software

\begin{tabular}{|c|c|}
\hline Sistem operasi & $\begin{array}{l}\text { Ubuntu } 16.0464 \text { bit } \\
\text { OS Linux Kernel 4.x }\end{array}$ \\
\hline Network & $\begin{array}{l}- \text { TCP } 80 \& 443 \\
-\quad \text { UDP } 16384 \quad- \\
32768 \\
\text { - ipv4 address }\end{array}$ \\
\hline bandwidth & $250 \mathrm{Mbps}$ \\
\hline hostname & vcon.walisongo.acid \\
\hline
\end{tabular}

Maka sesuai dengan standard minimal dari aplikasi dan penyesuaian yang dimiliki oleh UIN Walisongo maka, di rancanglah sebuah server yang sesuai dengan standar minimal dari developer dan memaksimalkan resource dari hardware yang dimiliki oleh perguruan tinggi menjadi sebuah server yang berdiri diatas diatas VMWare Vsphere dengan sepesifikasi seperti berikut :

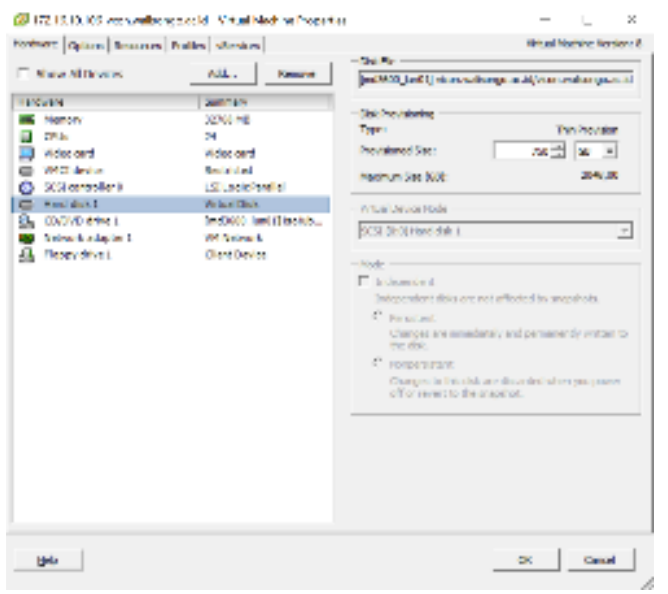

Gambar 2

Konfigurasi server vcon.walisongo pada VMware Vsphere

Tabel 3

Spesifikasi hardware Terinstall

\begin{tabular}{|l|l|}
\hline CPU & 24 Core \\
\hline RAM & $32 \mathrm{~GB}$ \\
\hline Hardisk & $750 \mathrm{~GB}$ \\
\hline
\end{tabular}

\section{c. Implementasi}

Pada tahap implementasi terdapat 2 tahapan, proses preinstalasi dan proses instalasi itu sendiri. Proses pre-instalasi adalah menyiapkan kebutuhan kebutuhan dari aplikasi BigBlueButton yang fokus kepada instalasi sistem operasi dan aplikasi pendukung serta hal-hal pendukung lainya di luar server seperti penyiapan domain dan jaringan, serta mendapatkan sertifikat SSL sedangkan pada proses instalasinya lebih fokus kepada teknik install BigBlueButton itu sendiri.

Berikut tahapan untuk proses pre-instalasinya : 
Implementasi Dan Analisis Server BigBlueButton Dalam Pemanfaatan Meeting Online Pada Masa Pandemic

1. Instalasi Ubuntu 16.0464 bit

Instalasi standard dari Ubuntu Server 16.0464 bit dengan service openssh server untuk remote server.

2. Konfigurasi Firewall

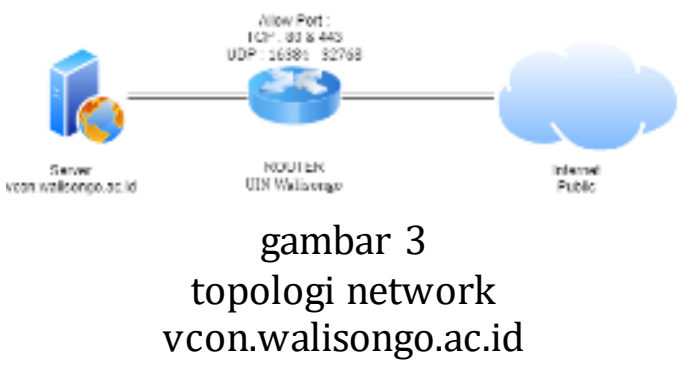

Topologi firewall yang akan digunakan BigBlueButton di server vcon.walisongo.ac.id seperti diatas, dimana port TCP $80 \& \& 443$ serta Port UDP 16384 - 32768 harus bisa di akses melalui server public. Sehingga server BigBlueButton bisa berjalan dengan baik.

\section{Setting hostname / URLName}

Hostname yang akan digunakan pada server ini menggunakan alamat vcon.walisongo.ac.id yang di setting di server hosting, dimana TLD walisongo.ac.id ditempatkan di hosting Rumahweb.com

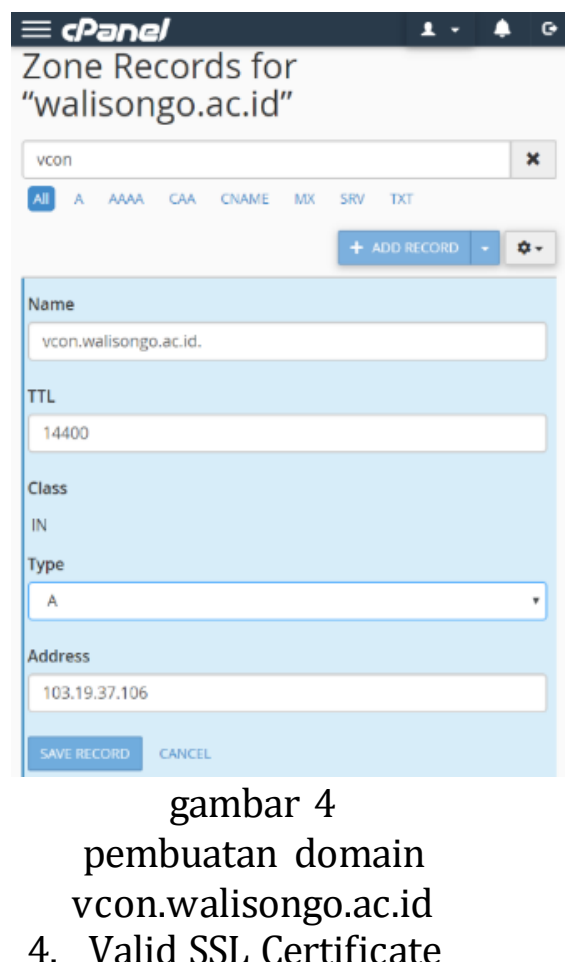

- Valid SSL Certificate

SSL sertifikat yang digunakan pada TLD walisongo.ac.id dan seluruh domainya menggunakan sertifikat GlobalSign Wildcard Domain SSL, yang disewa di rumahweb juga.

\section{Configure SSL Certificate \\ Product Details
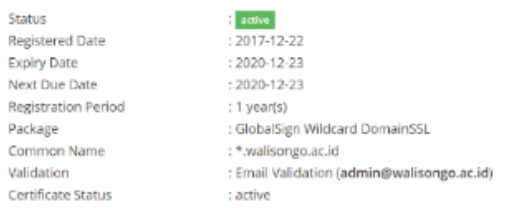 \\ gambar 5 \\ sertifikat SSL GlobalSign Wildcard}

Setelah tahapan pre-instalasi servernya sudah disiapkan, maka langkah selanjutnya adalah fokus terhadap instalasi BigBlueButton dengan tahapan seperti berikut : 
1. Update Server Ubuntu dan menambahkan repository BigBlueButton

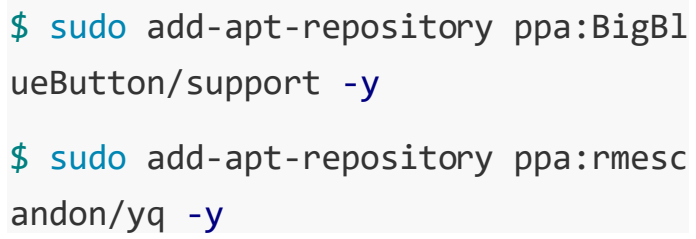

2. Install apt-get key untuk reposisotry BigBlueButton

\$ wget https://ubuntu.BigBlueButton .org/repo/BigBlueButton.asc -0- | s udo apt-key add -

3. Install BigBlueButton

Install BigBlueButton dan tambahkan BigBlueButtonhtml5 supaya support dengan html5 sehingga bisa diakses langsung melalui browser.

\$ sudo apt-get install BigBlueButto $\mathrm{n}$

\$ sudo apt-get install BigBlueButto n-htm15

4. Restart server lalu check service untuk memastikan :

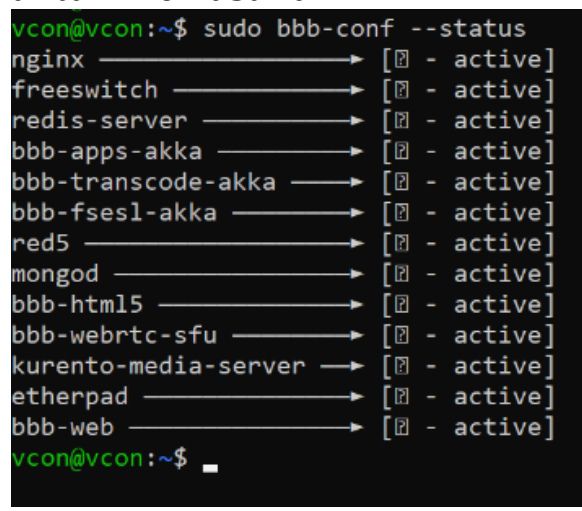

gambar 6

service yang berjalan

5. Server siap digunakan.
Untuk mengakses virtual Meeting ini bisa langsung diakses melalui laman https://vcon.walisongo.ac.id melalui browser sehingga setelah dicustom tampak hasil seperti berikut :

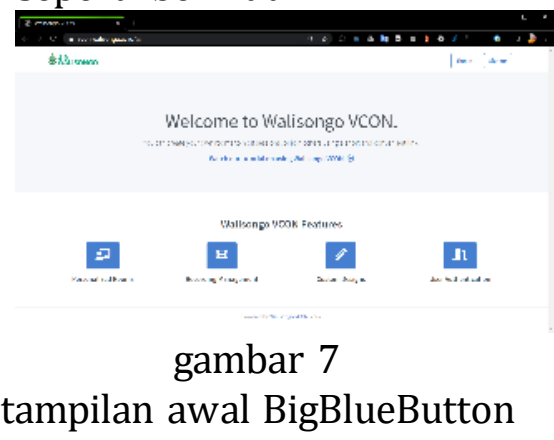

\section{d. Pengujian}

Pada tahapan pengujian ini, penulis fokus terhadap explorasi dari semua fitur - fitur yang ada pada aplikasi BigBlueButton dan kemampuan uji coba performa BigBlueButton dari sisi server. Untuk dapat melakukan explorasi dari semua fitur yang ada, kita harus membuat meeting room terlebih dahulu dan kita harus bertindak sebagai host / moderator, dengan cara mendaftar / Sign Up dengan menu yang tersedia, lalu login, sehingga akan tampak tampilan home seperti berikut :

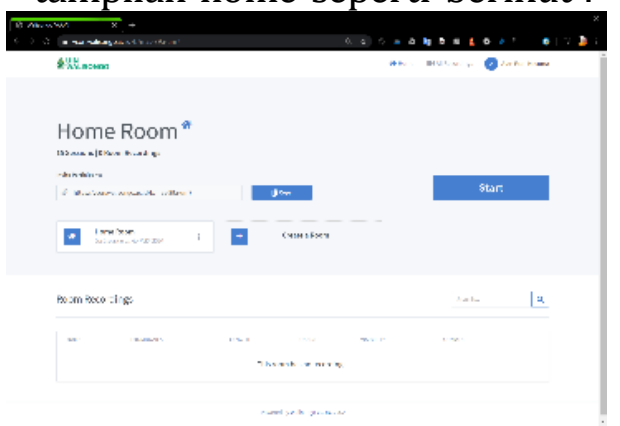

gambar 8 
tampilan home BigBlueButton

Dari gambar diatas, sudah bisa didapati beberapa fitur pertama dari BigBlueButton yakni create room meeting baru, Room recording untuk tempat penyimpanan, dan start meeting. Dan selanjutnya untuk mengexplore lebih lanjut bisa di tekan tombol start untuk memulai meeting.

Berikut merupakan hasil capture BigBlueButton dengan 3 peserta dengan menggunakan 3 perangkat yang berbeda

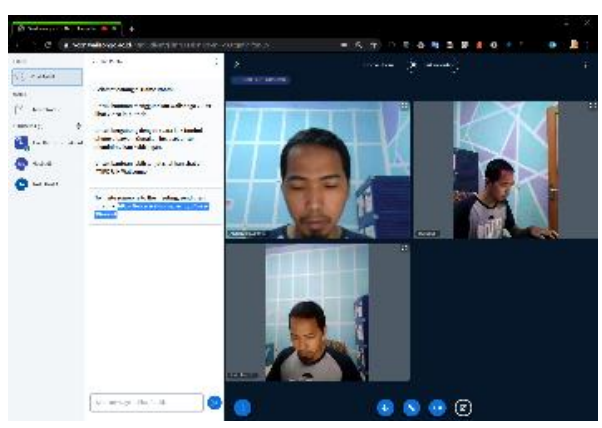

gambar 9

tampilan meeting online

BigBlueButton

Tampilan awal dari BigBlueButton yang diakses pada saat meeting online, dapat dilihat default seperti pada gambar diatas dimana terdapat area video conference, fitur chat public, dan daftar peserta conference. Selain itu ada beberapa tombol yang juga merupakan fitur - fitur yang perlu di explore juga. Seperti share screen, share presentation, start pooling, dan share video external semisal dari youtube.
Sedangkan pada saat presentasi, melalui share presentasi, bisa digunakan beberapa jenis file untuk presentasi, diantaranya file berextension .pdf, .docx, .pptx, .xlsx, dan file gambar.

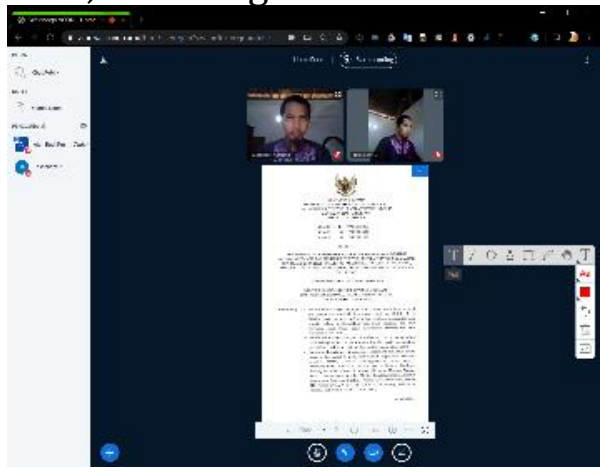

gambar 10

tampilan presentasi BigBlueButton

Selain beberapa fitur diatas, ada juga fitur share screen dari aplikasi di desktop, screen yang sedang berjalan, atau tab dari browsernya.

Sedangkan untuk explorasi dari sisi mobile, melihat dari tampilan desainnya BigBlueButton dengan teknologi html5 ini, merupakan aplikasi video conference yang didesain untuk pengguna mobile. Karena seperti halnya desktop dimana untuk menjalankan aplikasi BigBlueButton ini tidak perlu penambahan aplikasi khusus karena bisa langsung dijalankan menggunakan browser.

Dan tampilan antarmukanya pun bisa dibilang userfriendly, karena hampi semua fitur yang dibutukan dari sebuah meeting online dapat dilihat menggunakan BigBlueButton yang diakses melalui perangkat mobile. 


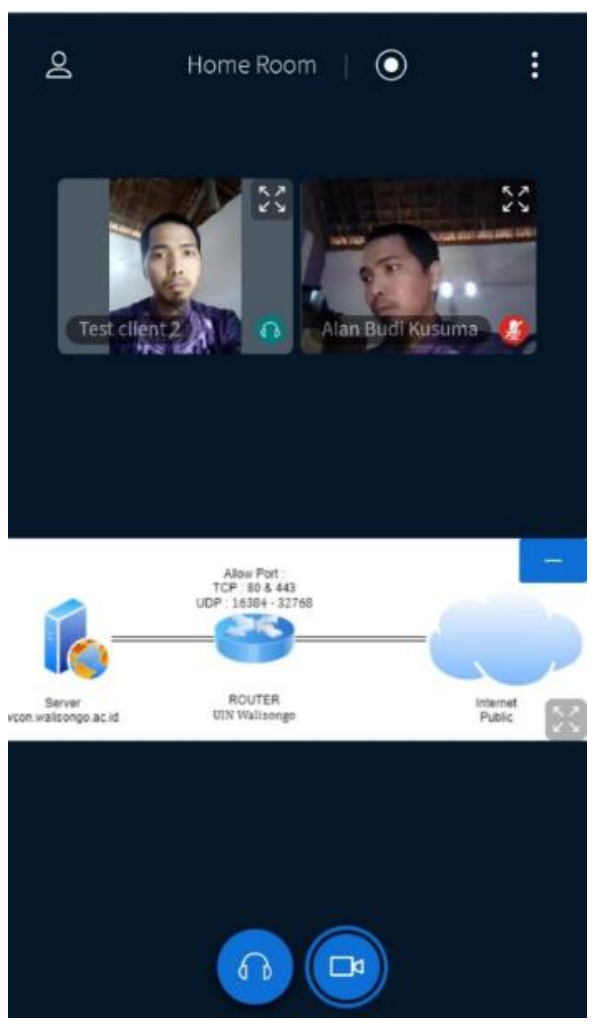

gambar 11

tampilan BigBlueButton diakses melalui android

setelah explorasi fitur selesai langkah kedua dalam ujicoba ini fokus terhadap kehandalan hardware server. Dan pada ujicoba coba ini digunakan untuk mengetahui seberapa besar kemampuan server untuk menampung meeting online yang dilakukan secara bersamaan. Dalam kasus disini, akan diuji dari kemampuan CPU dan memory yang digunakan saat dilakukan meeting online secara bersamaan. Ujicoba kemampuan hardware ini diambil pada hari Jum'at tangal 26 April 2020, diambil dari resource hardware melalui aplikasi htop dari Ubuntu server dan hasil outputnya seperti berikut :

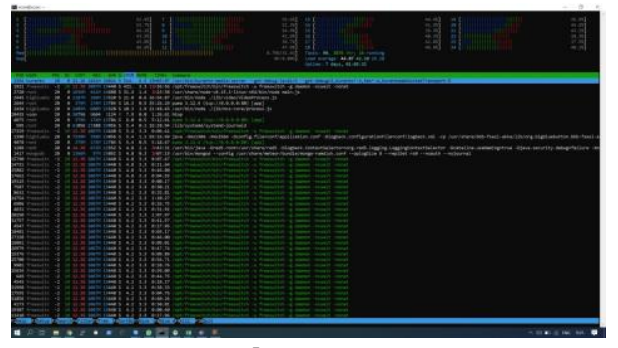

gambar 12

tampilan htop dari server

BigBlueButton

Sedangkan untuk mengetahui jumlah user yang sedang online dan meeting room yang sedang berjalan maka bisa dapat diperoleh melalui API yang disediakan oleh BigBlueButton, dimana resourcenya dokumentasi bisa didapatkan melalui situs di https://docs.BigBlueButton.org/ dev/api.html. Dan setelah ditemukan akses APInya dapat diperoleh hasil berupa format XML seperti berikut :

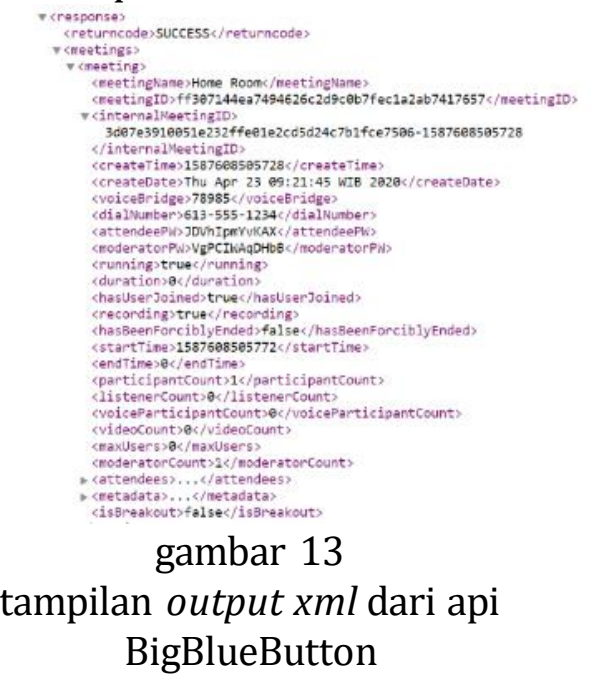

Setelah didapatkan output xml dari meeting yang sedang berjalan, maka 
Implementasi Dan Analisis Server BigBlueButton Dalam Pemanfaatan Meeting Online Pada Masa Pandemic

setelah di konversi file xml ke dalam file excel diperoleh hasil seperti berikut :

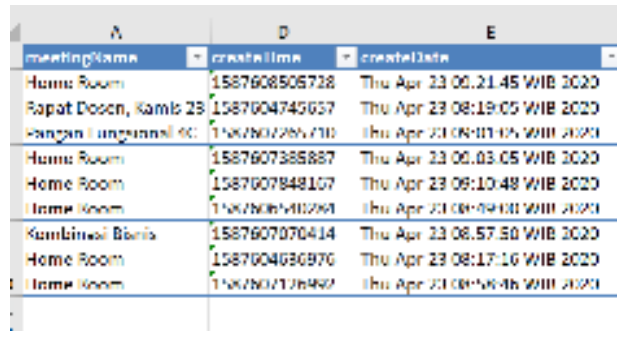

gambar 14

hasil konversi xml ke xls melihat meeting yang berjalan

\begin{tabular}{|c|c|c|c|c|}
\hline A & c & D & J & \\
\hline No & fullName & Frole & attendees_Id & $\sigma$ \\
\hline & Siti Komariyah & VIEWER & & 6 \\
\hline 86 & Risya Abqiya & VIEWER & & 6 \\
\hline & Nur Ainii Maghfiroh & VIEWER & & 6 \\
\hline & Nandy Hardianto & VIEWER & & 6 \\
\hline 89 & Mella Puji Firdayani & VIEWER & & 6 \\
\hline 90 & Sari Qurrota A'yuni & VIEWER & & 6 \\
\hline 91 & Alfiyan Fatahila & VIEWER & & 6 \\
\hline 92 & Dania Adelia Shavila & VIEWER & & 6 \\
\hline 93 & siti nur syarifah & VIEWER & & 6 \\
\hline 94 & Dilla Imroatun Azizah & VIEWER & & 6 \\
\hline 95 & Afrikhatul Afidah & VIEWER & & 6 \\
\hline 96 & Wahdaul ulyana & VIEWER & & 6 \\
\hline 97 & Uswatun Khasanah & VIEWER & & 6 \\
\hline 98 & Abdul Ghofur & MODERATOR & & 7 \\
\hline 99 & Muyassarah & MODERATOR & & 8 \\
\hline
\end{tabular}

gambar 15

hasil konversi xml ke xls berdasarkan peserta meeting

Setelah semua data diperolah selanjutnya data diolah dan dilakukan analisis kemampuan daya tampung dari server yang ada.

Maka dari itu, hasil dari gambar 12 dikonversi menjadi tabel penggunaan CPU didapatkan hasil seperti berikut :

Tabel 4

Spesifikasi penggunaan CPU

\begin{tabular}{|c|c|c|c|c|c|}
\hline $\begin{array}{c}\text { No } \\
\text { cpu }\end{array}$ & use & $\begin{array}{c}\text { No } \\
\text { cpu }\end{array}$ & Use & $\begin{array}{c}\text { No } \\
\text { cpu }\end{array}$ & use \\
\hline 1 & 51,9 & 9 & 54,9 & 17 & 42,8 \\
\hline 2 & 53,7 & 10 & 42,9 & 18 & 46,9 \\
\hline 3 & 66,1 & 11 & 36,7 & 19 & 45,9 \\
\hline 4 & 43,5 & 12 & 47,9 & 20 & 44,5 \\
\hline 5 & 43 & 13 & 44,4 & 21 & 43,2 \\
\hline
\end{tabular}

\begin{tabular}{|l|l|l|l|l|l|}
\hline 6 & 46,6 & 14 & 41,5 & 22 & 38,3 \\
\hline 7 & 55,6 & 15 & 29,3 & 23 & 37,5 \\
\hline 8 & 52,2 & 16 & 40,3 & 24 & 40,1 \\
\hline
\end{tabular}

Sehingga apabila digunakan rumus rata - rata didapatkan hasil penggunaan CPU seperti berikut :

$$
\bar{x}=\frac{\sum X i}{n}
$$

Keterangan :

$\overline{\mathrm{X}}=$ rata-rata jumlah penggunaan $\mathrm{CPU}$

$\sum X \mathrm{i}=$ Jumlah penggunaan $\mathrm{cpu}$ masingmasing core

$\mathrm{n}=$ jumlah core dikali $100 \%$

dimana didapatkan hasil dari $\sum X \mathrm{i}$ merupakan penjumlah dari semua penggunaan core cpu (dari tabel 4) sejumlah 1089,7 \% lalu dibagi jumlah core cpu (n) sebanyak 24 core dikali 100 (dalam\%) menjadi 2400, sehingga didapatkan hasil penggunaan ratarata cpu sejumlah 1089,7 / $2400 * 100$ $\%=45,404 \%$

sedangkan menurut gambar no 12 untuk penggunaan resource memory hanya didapati menggunakan resource memory sebesar 8,79 GB dari jumlah 31,4 GB memory yang terinstall sehingga penggunaanya hanya didapat angka 8,79GB / 31,4GB $* 100 \%=27,99 \%$ saja.

Oleh karena presentase memory dan penggunaan CPU lebih banyak penggunaan CPU, maka akan dianalisis lebih lanjut untuk mengetahui kemampuan server untuk menangani meeting online secara bersamaan.

Dengan menggunakan presentasi CPU sebagai acuan untuk kemampuan server. Maka didapati dari penggunaan total 24 Core CPU adalah 
45,04\% maka selanjutnya digunaakan sebagai pembagi dari angka maksimal $100 \%$ terus dikali dengan jumlah peserta pada saat kondisi core cpu mencapai angka 45,04\%. Maka didapatkan hasil berikut :

$(100 \% / 45,04 \%) * 99$ peserta maka didapatkan hasil 218,0617 sehingga dengan kata lain server BigBlueButton yang beralamat di vcon.walisongo.ac.id bisa menampung peserta sejumlah 218 peserta meeting yang dilakukan secara bersamaan

\section{PENUTUP}

Berdasarkan ujicoba implementasi dan analisis server meeting online menggunakan BigBlueButton yang beralamat di https://vcon.walisongo.ac.id maka diperoleh hasil :

1. BigBlueButton merupakan aplikasi opensource untuk meeting online yang memiliki fitur : diantaranya :
a. WebCam Sharing
Fitur WEb
b. VOIP integrated
c. Share Screen
d. Share Presentation
e. Hand Tool Presentation
f. Share Noted
g. Chat Public

h. Chat Private

i. Pooling

j. Moderate User

k. Share External Video

l. Video Recording

2. Mobile Support

Melalui teknologi html5 memungkinkan untuk dapat menjalankan BigBlueButton melalui browser langsung, baik dari pc desktop, ataupun dari perangkat mobile. Berbeda diperangkat lain, seperti zoom, webex, jitsi, google meet untuk pengguna mobile harus menambahkan aplikasi khusus yang bisa didownload melalu playstore

3. Dalam kemampuan hardware server dalam menangani server, didapat hasil analisis dari performa server dimana memiliki spesifikasi sejumlah 24 Core CPU, dan 31,4 GB memory yang diinstal bisa menampung peserta meeting online sejumlah 218 peserta.

4. Sebagai alternative untuk selalu bisa berkomunikasi / rapat secara online di tengah wabah pandemic global 


\section{REFERENCES}

BigBlueButton : API. (2020, April 23). Retrieved from https://docs.bigbluebutton.org/dev/api.html

BigBlueButton : Install. (2020, April 26). Retrieved from http://docs.bigbluebutton.org/2.2/install.html

Hardayanto, R. H., \& Surjono, H. D. (2016). Pengembangan dan Implementasi E-Learning Menggunakan Moodle dan Vicon Untuk Pelajaran Pemrograman WEB di SMK. Jurnal Pendidikan Vokasi, 42-53.

Ismail, M., Mulyana, A., \& Tulloh, R. (2016). Perancangan dan Realisasi Sistem Perkuliahan Jarak Jauh Dengan Mode Teleconference Berbasis Multimedia (Server Video Conference).e-Proceeding of Applied Science, 1304-1310.

Karibi, J. V., Husni, M., \& Anggraini, E. L. (2013). Pengembangan Web Conference pada Modul E-Learning Dokeos. JURNAL TEKNIK POMITS, 1-5.

Kompas. (2020, April 01). Hangouts, Zoom, Skype, dan Webex, Mana yang Paling Irit Data? Retrieved from https://tekno.kompas.com/read/2020/04/01/12010057/hangouts-zoom-skypedan-webex-mana-yang-paling-irit-data

Menteri Agama. (2020). Surat Edaran Nomor 5 tahun 2020 tentang Penyesuaian Sistem Kerja Pegawai dalam Upaya Pencegahan Corona Virus Desease (Covid-19) Pada Lingkungan Kementerian Agama. Kementerian Agama.

Nash, J. (1995). Pengertian Sistem Informasi. Jakarta: Informatika.

Nursyidiq, A. F. (2012, 05). Video Conference. Retrieved from http://fajarawal.blogspot.com/2012/05/video-conference.html

O'Brain, J. (2008). Pengantar Sistem informasi. Jakarta: Salemba Empat.

Pressman, R. S. (2010). Pendekatan Praktisi Rekayasa Perangkat Lunak. Yogyakarta: Penerbit Andi.

Sekretaris Jendral. (2020). nomor SE/57/IV/2020 Tentang Aplikasi Teleconverence zoom tidak dipekernankan / digunakan di lingkungan kementerian terkait pengaman informasi data. Jakarta: Kementerian Pertahanan. 
Alan Budi Kusuma ${ }^{1}$, Amir Yusuf ${ }^{2}$, Alfian Hidayat ${ }^{3}$

This page intentionally left blank. 